\title{
COGENERATION: AN OVERVIEW
}

\section{J. THOMAS BRETT*}

The author examines the various energy contracts which support a typical natural gas fired cogeneration project, including power purchase contracts, steam contracts and gas supply contracts. Cogeneration projects are also considered in the context of investment opportunities, including the relevant Canadian income tax provisions.

\section{TABLE OF CONTENTS}

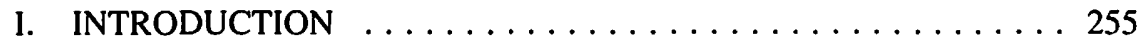

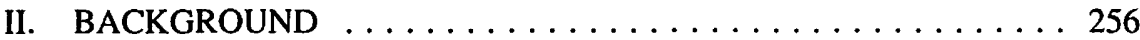

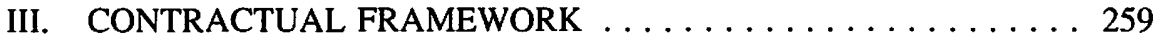

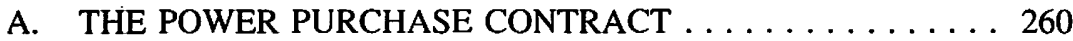

B. THE STEAM CONTRACT $\ldots \ldots \ldots \ldots \ldots \ldots \ldots \ldots 263$

C. THE NATURAL GAS CONTRACT ............ 265

IV. COGENERATION PROJECTS AS INVESTMENTS . . . . . . . . 269

\section{INTRODUCTION}

Oil and gas producers in Canada are increasingly supplying gas under long-term contracts to cogeneration projects in both Canada and the United States. For this reason, as well as the fact that Canadian income tax laws provide oil and gas producers and marketers with very substantial tax shelters in the form of accelerated capital cost allowances on their investments in cogeneration projects, producers and their advisors should be knowledgeable about the cogeneration business.

This paper addresses the principal energy contracts that are used in gas-fired cogeneration projects, namely the power purchase contract between the cogenerator and the electric utility, the steam contract between the cogenerator and the industrial steam buyer, and the gas supply contract between the gas producer and the cogenerator. In addition, it will review provisions of the Income Tax Act Regulations (Class 34), that provide capital cost allowances for cogeneration project assets and a possible structure for oil and gas producers' investment in these projects.

The paper does not propose to discuss all the important contracts necessary to implement a cogeneration project. For example, neither the engineering and construction contracts nor the loan agreements have been dealt with. These are more generic than the gas, steam and electricity contracts, and will be more similar to the contracts with which you are familiar, save perhaps for the fact that cogeneration projects are typically financed on a project or non-recourse basis. 


\section{BACKGROUND}

Cogeneration is the simultaneous production of electricity and heat. These products can be produced by a variety of turbine and generator configurations, the most common one being a gas turbine which produces both electricity and exhaust heat. The electricity is sold directly to an electric utility, or utilized in whole or in part by the plant owner. The exhaust heat is used to produce steam in a heat recovery steam generator, which generates process steam which is supplied to a nearby industrial plant, and in a combined cycle will pass through a steam turbine to generate additional electricity. Surplus steam made in this way would pass through the steam turbine to a condenser. Because cogeneration facilities produce both electricity and heat, they can operate at a conversion efficiency of over $80 \%$, considerably higher than the $30 \%-40 \%$ typical of electric power plants. However, depending on the steam host demand and use of a condensing steam turbine, the efficiency could be as low as $45 \%$.

The increased efficiency results in lower unit energy costs. While a variety of fuels can be used, natural gas has become the preferred fuel option for cogeneration plants in the United States and Canada because of dependable gas turbine technology, ample gas supplies, environmental advantages of gas relative to coal, and relatively low costs.

Cogeneration predated the development of large public electric utilities in North America, but its modern reincarnation began with the passage of the Public Utility Regulatory Policy Act (PURPA) in the United States in 1978. Prior to PURPA, cogeneration in Canada and the United States developed in a parallel fashion, often in the pulp and paper and chemical industries, either because of a large demand for steam and electric energy or due to the plants' remote location or the poor reliability of the electric utility. Dow Canada at Sarnia was the first cogenerator to use gas-fired combustion turbines with heat recovery steam generators and steam turbines to supply the electric and steam energy needs of their chemical manufacturing site. PURPA required electric utilities in the United States to purchase electricity from qualifying cogenerators, and to pay the cogenerator their "avoided-cost" from not having to construct that capacity. The details of implementation, including the method of determining the utilities' "avoidedcost," was left to the state regulators to work out. With the stimulus of PURPA, the independent power industry (power generators that are not regulated as "public" utilities), has grown rapidly in the United States since 1978, to the point where installed capacity at the end of 1990 reached approximately 40,000 megawatts (MW), equivalent to $5 \%$ of total U.S. capacity. About $16,000 \mathrm{MW}$, or $40 \%$ of the total is fuelled by natural gas. That amount may be compared with the size of Ontario Hydro, with installed capacity of about $30,000 \mathrm{MW}$.

In 1990, more new electrical generating capacity has been committed by independent generators, most of whom are PURPA qualified cogenerators, than by traditional regulated utilities. In 1990 alone, 224 projects totalling 6,356 MW entered service, and another 268 projects representing $35,000 \mathrm{MW}$ were announced, nearly three times the totals announced in 1988 or 1989. Recent projections call for an additional 45,000 to $60,000 \mathrm{MW}$ of independent power to be installed by the year 2000 . Natural gas should capture in the range of $40 \%-50 \%$ of that increment. Since a $50 \mathrm{MW}$ gas-fired cogeneration facility 
uses in the order of $13 \mathrm{mmcf}$ per day (4.7 bcf per year) of natural gas, cogeneration and independent power production represent a substantial new market.

The areas of greatest concentration in the United States have been Texas, with its large appetite for steam for its petrochemical and refinery facilities, California, where utilities initially paid relatively high avoided cost rates for power and the Northeast, where energy costs are relatively high and environmentally acceptable alternatives limited, and where, until recently at least, there has been a rapidly increasing demand for power.

The post-PURPA cogeneration industry in the United States was launched by several independent cogeneration development companies, often started by a few individuals with previous utility, energy policy, financing or engineering experience, or by companies in related fields, for example, the provision of auxiliary boilers. Given the competitive nature of financial markets in the early to mid-1980's, many early projects were financed on a highly leveraged basis, some at virtually $100 \%$, so that corporate "deep pockets" were not required. More recently, different companies have entered the business. Over 35 electric or gas utilities have established non-regulated affiliates to develop and own projects. Major gas pipeline companies have followed suit, as have some of the largest design-build engineering firms. There are, at this time, several hundred cogeneration development companies in the United States of which perhaps 80 or 90 could be deemed to be major industry players, and competition for projects is intense. (Many utilities have adopted competitive bidding programs to acquire needed capacity at the lowest possible cost, and have successfully maintained that such bids constitute their "avoided cost"). Many joint ventures have been established to pool the skills of various participants. For example, some utilities have formed companies with established independent developers.

In addition, in the last few years, an independent power project (IPP) market has developed in the United States. These plants are not PURPA qualified cogenerators, but coal or gas-fired electric power plants that are developed and owned by independent power producers, rather than regulated public utilities and that sell their power to other regulated utilities. They may be exempted from provisions of the Federal Power Act which would require them to sell their power on a cost of service basis, and may sell power at market determined prices provided that they meet Federal Energy Regulatory Commission (FERC) criteria, including one relating to absence of market dominance.

At least 20 to 25 U.S. cogeneration or independent power projects are utilizing, or propose to utilize, Canadian gas for all or part of their fuel. A number of Canadian companies are supplying gas to the giant Midland Cogeneration Facility in Michigan, essentially a gas repowering of a partly completed nuclear facility. More typical are a whole series of cogeneration projects, mainly in New York state, New England and, to a lesser extent, in the mid-Atlantic states, in the 50-100 MW range. The Dartmouth Power Associates project is an example of an IPP supplied by Canadian gas. Export licences are now routinely issued by the National Energy Board (for gas exports to these projects). The U.S. power market for Canadian gas, which includes cogeneration, independent power projects and utility owned gas-fired power plants, is projected to grow rapidly over the next few years. 
In Canada, there is no equivalent to the PURPA legislation. However, particularly in Ontario and British Columbia, pressure from private industry, including potential developers, increasing electricity rates, large Hydro deficits, and in Ontario, public concern about nuclear power and therefore pressure from government, has led to increased utility willingness to purchase power from independent generators. In Ontario, two gasfired cogeneration projects have been completed, and several more are under construction or in the permitting stage, and 6,000-7,000 MW of projects, most of which are gas-fired, have been proposed to Ontario Hydro. Ontario Hydro has publicly committed to a target of 3,100 MW of independent power by the year 2000, although most observers believe the actual number will be significantly larger.

The Environmental Assessment Board in Ontario has recently commenced a review of Ontario Hydro's 25 Year Supply/Demand Plan. One of the major issues in that hearing is whether the price Hydro now pays independent generators for electricity, approximately $4.2 \notin$ per kwh, represents Hydro's true avoided cost. The Ontario Government has stated that as a matter of policy, Hydro should pay its avoided cost. If Hydro were to increase the price it pays by between $0.5 \notin$ and $1 \notin$ per kwh, many more projects would become economical.

Hydro-Quebec is also interested in purchasing power from independent generators, including gas-fired cogeneration. While only one small project is now in operation, several more projects in the 50-100 MW range are currently under negotiation. HydroQuebec pays approximately the same as Ontario Hydro for electricity. Cogeneration developers have proposed much more gas-fired cogeneration or gas-fired power plant capacity than Hydro-Quebec currently requires. While it has set a target of $750 \mathrm{MW}$ of cogeneration by 1995, it has received proposals for 3,000 MW of cogeneration and gasfired power plants.

In British Columbia, B.C. Hydro has signed contracts with independent power producers for some $250 \mathrm{MW}$ of energy, for domestic use, over the next three to four years. One of these projects is gas-fired cogeneration, the remainder are wood waste and small hydro. While B.C. Hydro has decided not to proceed with further Requests for Proposals for independent power, it will enter into what it characterizes as "selfgeneration" projects, projects which displace an existing industrial user's power purchases. There are some opportunities for projects of this type in the pulp and paper industry in B.C. B.C. Hydro will purchase as much power as is necessary to allow the matching of gas turbine equipment with the industrial facility's electric load. In addition, several gasfired cogeneration projects have been proposed to sell power into the export market, either directly to U.S. buyers, or through Powerex, B.C. Hydro's export marketing affiliate. Powerex proposals have recently been short-listed in a competitive bid by the Sacramento Municipal Utility District. B.C. Hydro will also wheel electricity on behalf of cogenerators to purchasers elsewhere in the province or for export.

Since power purchase rates are generally lower in Canada than in the United States, industrial companies which are prepared to pay a market price for steam are more critical to the viability of a Canadian project. In general, steam revenues represent a higher percentage of total project revenues in Canada than in the United States. Sometimes they 
may account for as much as $20 \%-25 \%$ of total project revenues. In the United States, a steam customer is required only to meet the efficiency tests under PURPA. In Canada, substantial steam production relative to the electricity produced is normally required for the project to qualify for Class 34 treatment under the Income Tax Act. Industries that have a large continuous demand for steam or some other form of heat are the best "partners" for cogeneration developers. These include pulp and paper mills, petrochemical facilities, metallurgical smelters, refineries and some food processing companies. To qualify for tax Class 34, developers in Canada must find an industrial company willing to purchase steam from its cogeneration plant. In the United States, because of higher electricity prices and the partial deregulation of the electricity industry, that is not the case. Non-PURPA qualified gas-fired independent power projects are viable in many cases. A good example is the Dartmouth Power project in Massachusetts noted earlier.

In Canada, the cogeneration industry has developed differently than in the United States. The first players into the business have been, with one notable exception, gas and electric utilities through unregulated subsidiaries. The first gas-fired project completed in Ontario, at the Boise Cascade pulp and paper mill in Fort Frances, was developed by a division of what is now called Centra Ontario Ltd., formerly ICG Utilities (Ontario) Ltd. Transalta Energy Systems, a subsidiary of Transalta Utilities, has announced two gas-fired projects in Ontario, one of which is currently under construction. The exception is an independent developer, Northland Power, which has successfully developed two wood and natural gas-fired projects in northern Ontario. The cogeneration division of Consumers Gas is proposing to develop several projects in Ontario. TCPL Cogeneration Ltd., the cogeneration affiliate of TransCanada PipeLines Ltd., has one project under construction at its Nipigon compressor station and several more planned, both alone and with joint venture partners.

More recently, a number of U.S. cogeneration developers have entered the Canadian market. These include: Indeck, a U.S. independent; Destec, an affiliate of Dow Chemical; Long Lake Energy, an Independent; Mountain Energy Inc., an affiliate of Green Mountain Power; Nordic Power, another independent; Mission Energy, a large utility affiliate; Sithe L.P, an affiliate of a French utility; and Enron Power, an affiliate of Enron Corporation, an interstate gas pipeline. Westcoast Energy Inc. has developed a gas-fired project in British Columbia with CU Power, the cogeneration affiliate of Canadian Utilities Ltd. The latter company is also involved in a large gas-fired cogeneration project in Great Britain.

\section{THE CONTRACTUAL FRAMEWORK}

In legal terms, cogeneration projects may be thought of as an interlocking network of long-term contracts. The two products of the project, electricity and steam, are supplied under long-term contracts to the utility and the industrial steam "host" respectively. The plant is often built by the cogeneration developer on land purchased or leased from, and adjacent to, the steam purchaser's facilities. Natural gas is supplied to the project under a long-term contract. The developer is able to obtain long-term debt financing for the project based on these three contracts. The cogeneration facilities are often, though not always, "project financed," in that the project lenders have recourse only to the project 
itself to repay their loan, not to the developer's other assets. Projects are often financed on the basis of $75 \%-80 \%$ debt and $20 \%-25 \%$ equity. The relatively high leverage is possible because of the relatively stable nature of the revenue stream, and the predictability of the operating and fuel costs. The profitability of the project for the developer depends on the spread between the revenue from the electricity and steam sales, and the fuel, operating and maintenance costs, and interest charges on the debt. The project owner must ensure, through careful planning and coordination of the various contracts, that the project generates a positive cash flow over its life as well as sufficient overall returns. It would be difficult, for example, for a developer to incur the risk that the gas price in a given year would increase by a much larger percentage than the electricity and steam prices. A developer will also enter into a design-build contract to construct the project, and that contract will contain provisions to limit the risk of cost overruns and performance guarantees.

\section{A. THE POWER PURCHASE CONTRACT}

The detailed terms of power purchase contracts vary from one electric utility to another but some issues are common to all of them.

\section{Take-or-Pay}

Most Ontario Hydro contracts provide that the utility will take all the power and energy the cogenerator can produce, at least up to an agreed-upon level. PURPA qualified facilities in the United States will generally be "must run" facilities, not subject to economic dispatch by the purchasing utility. Economic dispatch occurs when electric utilities or power pools to which the utilities belong shed generation capacity in order of decreasing operating costs, the most expensive units to operate being curtailed first. For example, the New England Power Pool (NEPOOL) operates in this fashion. The NEPOOL agreements dispatch power output for all the 93 utility participants' generating facilities on an incremental cost basis. For natural gas, the wellhead commodity price plus transportation commodity costs establish the incremental cost. The relationship of this cost to the incremental cost of other fossil fuels, together with the high efficiency of cogeneration units, should result in a relatively high rate of dispatch for gas-fired units. More precisely, they will rank behind hydro, nuclear and some coal-fired generating stations, but above oil fired facilities.

There can be no take-or-pay clause in this regime, and the developer and fuel supplier must estimate where the proposed project will rank in the cost hierarchy of plants for the utility or the pool. However, the power purchase contracts may circumscribe the utility's right to curtail purchases from the facility, by stipulating a maximum frequency of such curtailments per year. In addition, one of the arbitration criteria in the price redetermination clause of the gas contract for the project may be that the plant should be sufficiently competitive to be dispatched a minimum number of days per year.

While PURPA projects are not subject to dispatch rules, PURPA does contain a socalled "light loading" exemption, which permits utilities to curtail purchases from qualifying cogenerators when operational circumstances are such that the purchase would 
result in costs greater than the utility would incur if it did not make the purchases. An example of this would be a utility with a large hydro-electric generating capability, which would not wish to purchase power from cogenerators if the result were that it would be "spilling water" over its dams. The scope of this exemption has been very recently clarified for New York cogenerators by the New York State Public Service Commission, as not equivalent to a right of economic dispatch. Developers try to circumscribe the light loading exemption by further clarifying the circumstances in which it might be invoked, for example, to accord its plant a priority over plants that come on line at a later point in time. The producer must understand the regulatory regime of the state or province where the cogeneration facility will be located, as well as the operating characteristics of the utility purchasing the power.

\section{Energy and Capacity}

The electric utility purchases both energy and capacity from the cogenerator, notwithstanding the fact that one "blended" payment is made which is expressed in terms of cents/kilowatt hour. Energy, expressed in kilowatt hours, is required on an ongoing basis each day of the year. Capacity, or power, expressed in kilowatts, represents the maximum ability of the utility's system to serve its load on a peak load day. The utility calculates avoided costs for both energy and capacity, on the assumption that it is in an expansion mode and requires new capacity in the foreseeable future. If it does not require capacity in the foreseeable future, it will pay only for energy.

The avoided energy cost is the cost of the energy the utility would have to produce over the relevant period of time had it not purchased energy from the cogenerator. Most utilities may have two different avoided costs for energy, one for peak and another for off-peak hours. Similarly, the avoided capacity cost is the utility's saving from not having to construct a new unit because of the cogenerator's coming on line. Unlike avoided energy costs, avoided capacity costs are only relevant to the peak periods. The utility will pay up to its avoided cost for electricity. Ontario Hydro first calculates the present value of the avoided cost of the proposed cogeneration facility. It will then pay up to an equivalent amount, on a present value basis, for the electricity from the project over its life. They are prepared to overpay in the early years, under certain circumstances, and underpay in the later years, provided that the present value of that revenue stream does not exceed the present value of the avoided cost. The practice of front-end loading provides the owner with revenues in the early years to assist with interest and principal payments on the debt. The fact that Ontario Hydro uses a lower discount rate than the developer affords the developer a further benefit.

\section{Pricing Formula}

While the basic principle is that the utility pays up to its avoided cost, the payments under the power purchase contract may be broken down into several components and each component may be escalated at a different rate. Capacity payments will be made only for the electricity supplied during the peak periods and are contingent on the cogenerator meeting performance standards, often $75 \%-80 \%$ of nameplate turbine capacity. Failure to meet the standards result in pro-rata reductions in capacity payments. These standards 
and the test to support them are often contained in schedules to the contract, which incorporate current utility practice.

An approach sometimes used by Ontario Hydro is to try and fine tune the payments to the particular circumstances of the developer, giving the latter less risk but also probably less profit. In the simplest case, the energy payments may be indexed in part to Hydro's large direct customer power sales rate, and in part by a fixed percentage increment annually, and capacity payments may be fixed for 20 years. In a more elaborate agreement, the rate may contain: a cost of capital component, with little or no indexing; a gas commodity price component indexed to Hydro's industrial power sales rate, but allowing for periodic renegotiation within certain prescribed ranges; a gas transportation component consisting of the sums of the demand and commodity transportation tolls on each of the Canadian pipelines through which the gas moves; and an operating and maintenance component, perhaps escalated at the Consumer Price Index. The payment may even vary with the eventual cost of project debt or the final capital cost of the project.

The early U.S. projects had payments for energy and capacity which were escalated according to the increases in the utilities avoided cost. The trend now seems to be toward disaggregation of the payments under the power purchase contract into components which more accurately reflect the component of the developer's costs, share the risk and reduce the opportunity for windfall profits.

\section{Other Issues}

Several other issues arise in the negotiation of power purchase contract, including security for pre-payments, indemnities, term, milestones, and utilities' curtailment rights.

The contracts are long-term in nature, typically 20 to 25 years. If the utility agrees to pay the cogenerator more than its avoided cost in the earlier years of the contract, it will require security for all or part of the overpayment either in the form of a letter of credit or a second mortgage on the facility (the project lender will typically hold the first mortgage). The contracts will often contain milestones for the financing and construction of the project, which the developer must meet or be in breach. Occasionally the cogenerator will make a cash deposit which may be forfeited in the event the milestones are not met. The utility will indicate the minimum term (15-20 years) and preferred style of gas contract necessary, and may condition their power purchase contract on the cogenerator's obtaining a fuel contract which meets their requirements. It will require, at a minimum, a letter of intent with the gas supplier giving details of the source, transportation arrangements, term, and proposed pricing formula.

As noted earlier, many contracts will have penalty/bonus provisions related to the output from the plant relative to its rated capacity. Care must be taken in negotiating such contracts to ensure that these clauses represent actual damages to the utility rather than penalties. There is some room for marginal increases in output of the gas turbines based on ambient temperature and changes in the steam load, and contracts have some flexibility to accommodate increased electricity production. 
The contracts typically permit the utility to curtail purchases during conditions of system emergency, and with proper notice so that the cogenerator can coordinate his own schedule for maintenance with that of the utility, for maintenance and repairs on that portion of its system immediately adjacent to the cogenerator's plant, as well as during conditions of minimum loading noted above.

Finally, the contracts will contain mutual indemnification provisions, force majeure clauses, and specifications of operating conditions for the cogeneration plant, including power quality and system security. These latter criteria are often incorporated by reference from utility or pool operating standards, and may be the subject of a separate operating agreement. The cogenerator typically pays for the interconnection with the utility, although part of the equipment may be owned by the utility.

\section{Wheeling}

In the United States the cogenerator may sell the power to a distant utility and contract with the contiguous utility to transport or "wheel" the electricity to the ultimate purchaser. While wheeling in not yet mandatory in all cases under U.S. law, it is fast becoming a fact of life, given the ongoing deregulation of the electricity industry and the FERC's inclination to make transmission access a condition for electric utilities either to merge or to sell power through affiliates at market rates, rather than on a "cost of service" basis. Wheeling is not yet well accepted in Canada. Ontario Hydro will permit wheeling between facilities of a single owner (for example, a company that owns three or four pulp and paper mills in the province) but will not permit wheeling to unrelated third parties either within or outside the province. B.C. Hydro will permit wheeling for cogenerators to unrelated purchasers either within the provinces or within the Province or in the export market.

\section{B. THE STEAM CONTRACT}

Steam revenues account for approximately $20-25 \%$ of the revenue of a cogeneration project in Canada and also qualify the project for Class 34 treatment. In the United States the steam load is necessary for qualification under PURPA. The industrial steam purchaser will be concerned about the security of steam supply, since it is vital to its process and even brief shut-downs can be extremely costly. It will typically be necessary for the cogenerator to maintain auxiliary or back up boilers in readiness at all times. Because steam cannot be transported efficiently over long distances, the cogeneration facility will be located adjacent to the steam purchaser, on land purchased or leased by the cogenerator. Water for raising steam, or for cooling if required, will often be supplied by the steam purchaser.

The contract will normally require the cogenerator's facility to be operated on a continuous basis, at pressures, temperatures, and other specifications set out in the contract schedules, for a period of 20 or 25 years. Some U.S. contracts will require the steam purchaser to purchase sufficient steam for the cogenerator to maintain its PURPA status and to purchase all its steam requirements from the cogenerator, but often there will be no firm take-or-pay obligation. While steam revenue is not important to the economic 
viability of the American cogeneration projects, in Canada, as noted earlier, lower electricity prices increase the relative importance of steam sales and make higher minimum takes in the steam contracts customary and necessary.

Except in the event of force majeure, failure to supply the agreed upon amount of steam will result in liquidated damages, often equivalent to the difference between the steam cost in the agreement and the cost or some portion thereof to the host, of providing the steam from its own boilers. Failure to meet contract milestones for commencement of steam production will result first in liquidated damages, and ultimately in the purchaser's right of termination.

The initial price of steam is sometimes indexed to the natural gas (or oil) price as, were it not for the cogeneration project, the purchaser would have been fuelling its boilers with either of those fuels. Some steam contracts in Ontario index the steam price to the increase in Ontario Hydro's price to large industrial users. This is done on the condition that in the event that the resulting price increase is less than an agreed minimum annual escalation factor, the buyer would pay a percentage (equivalent to the percentage of the cogenerator's revenues that steam represents) of the amount by which the cogenerator's actual gas price exceeds the gas price that would have resulted from the application of the Hydro rate increase to the previous year's price.

In the U.S. contracts, closure of a plant prior to the expiration of a contract relieves the buyer from its obligation to take even a minimal amount of steam. The cogenerator is usually entitled to retain its lease, easements and water supply and acquire additional land from the host to construct a new steam host in order to maintain its PURPA status. Plant closure in Canada is a more serious economic matter. One contract provides for the payment of liquidated damages in the event of closure in the first seven years of the contract. In years 7-20, the steam host may close its plant without penalty and Ontario Hydro, in that event, agreed to increase the price it pays for electricity or, in the alternative, may purchase the facility under terms specified in the power purchase agreement. It is unlikely that Ontario Hydro would make a similar commitment in a future transaction.

Some Canadian utilities would like the option to require the cogenerator to redirect its steam production to produce more electricity in the later years of the contract. Attention should be paid to whether such a provision, even if it were not to take effect until some point several years in the future, would disqualify the facility for Class 34 treatment. Provisions which allow for a temporary increase in electricity during the electric utilities' peak demand period and a decrease in steam supplied to the steam host from the cogeneration plant leading to a temporarily lower cycle efficiency do not disqualify the cogenerator from Class 34 treatment as the qualification is based on the average annual heat rate. 


\section{THE NATURAL GAS CONTRACT}

\section{Introduction}

Cogeneration projects neither in Canada or the United States are a new, growing, longterm, high load factor market for Canadian gas. Natural gas comprises $50 \%$ to $60 \%$ of the life cycle costs of a cogeneration project. Long-term gas contract for cogeneration projects typically contain minimum annual escalation provisions and thereby provide a hedge for producers against other short-term sales, or sales under long-term contracts which are renegotiated annually to the market, as are many local distribution company (LDC) contracts.

\section{Take-or-Pay}

The contracts typically have terms of $15-20$ years, close or equivalent to the terms of the power purchase and steam contracts, and long enough to support the project's financing. Cogeneration facilities are designed to operate at load factors of at least $85 \%$ if they are base load or "must run" facilities and not subject to economic dispatch. There are often, but not always, annual minimum take provisions, ranging upwards from $50 \%$ to $60 \%$ of the maximum quantities the seller undertakes to provide. The buyer normally agrees to purchase all its gas requirements from the seller. If there is a minimum take clause, there are usually make-up or credit provisions if the buyer falls below its minimum take provision in any given year. (Some recent contracts contain provision for payments for deficiency payments or "reservation charges" in the event the buyer's annual take declines below a fixed percentage of the maximum daily quantity).

In lieu of take-or-pay provisions, the seller may have the right to reduce its annual deliveries to the level actually purchased by the buyer in the preceding two years, or may have an actual right of termination. Conversely, occasionally the buyer will have the right to self-displacement on payment of a penalty, after an initial period. The daily, annual and term quantities may normally be adjusted upward or downward by relatively small amounts by mutual agreement, to take into account the seasonal operating variations of the gas turbines and maintenance outages.

Contracts normally provide that gas not taken can be sold by the producer to third parties. Some also contain a supply retention fee or a supply retention fee in addition to a minimum take clause.

\section{Reserves}

Long-term contracts for cogeneration projects are deliverability rather than reservebased contracts, in that the seller warrants a continuous daily and annual quantity of gas over the contract term. However, utilities such as Ontario Hydro insist that the developer's gas contract provide for the dedication of sufficient reserves to satisfy at least the initial ten years of contract, with a 5-10 year rolling reserve requirement on a year-byyear basis. Discretion is exercised in this area in that the utility makes a judgement about the capacity of the producer. The lower revenue/production ratio is likely to be available 
only to the most credible producers. The producer has the right to substitute comparable reserves on a regular basis. Some U.S. utilities will accept a five year rolling reserve requirement. However, the Alberta Energy Resources Conservation Board (ECRB) has to date, required reserves dedicated to the contract sufficient to satisfy the contracted volume over its term. The National Energy Board's position is somewhat more flexible in that it will accept partial dedication of reserves and delivery capability covering approximately the first half of the contract term.

\section{Commodity Pricing Provisions}

In general the gas producer attempts to obtain market sensitive prices, while the cogenerator wants a gas price indexed in a manner which produces a predictable margin between revenues and gas costs. Several alternative gas pricing provisions are possible. One current approach that is reflected in some contracts between producers and cogenerators in Canada is to index the agreed first year gas price to the increase in price the utility pays the cogenerator. In Ontario, as noted earlier, Hydro escalated its initial payment determined on the basis of its avoided cost, by the annual percentage increase in the price Hydro charges its largest industrial customers for electricity. This schedule will be subject to both a minimum and maximum annual increase. Some early contracts were of this type. They were premised on some producers' views that over the long-term, the price of gas and electricity would increase more or less in tandem. Hydro's rates are projected to increase $8 \%-11 \%$ per annum over the next few years. Had a producer signed a contract two years ago indexed in such a fashion, the results to date would have been relatively satisfactory.

A second approach with respect to Ontario projects, which has been accepted by Ontario Hydro, is for the gas contract to permit periodic "reopeners" over its term, typically at years five and ten, where the gas price can be "marked-up" or "marked-down" to market levels, subject to a cap on the adjustment in either direction of between $15 \%$ and $25 \%$. In the intervening years, the gas price is indexed to the power purchase rate increase. The burden of the adjustment is then shared among Ontario Hydro, the steam purchaser and the cogenerator, pursuant to the terms of the power purchase and steam sales agreements. In one early Ontario contract, Ontario Hydro accepted $56 \%$ of the potential increase in gas price through agreed increases to the purchase price of electricity.

A variation of the "reopener" approach is to have escalation provisions based on Hydro's direct industrial sales rate, subject to minimum and maximum limits for the first half of the contract, and reopeners thereafter. This recognizes the developer's need for certainty in the early years when principal and interest payments on the project debt reduce operating profits, as well as the likelihood of increasing gas prices in the medium term.

Ontario Hydro's power purchase rates are the subject of annual Ontario Energy Board hearings. The Ontario Energy Board then recommends rates to the Cabinet of Ontario. The final decision is made by Cabinet. The utility is not regulated in the conventional sense, and some recommendations of the Ontario Energy Board are taken more seriously than others. On the one hand, it is reasonable to anticipate downward pressure on 
Hydro's proposals for rate increases from the government. At the same time, Hydro's financial position continues to tighten and it will be necessary for it to have both reasonable rate increases and devolve a larger responsibility for generation to the private sector. It is also likely that the Environmental Assessment Review Board's ongoing hearing on Ontario Hydro's Supply/Demand Plan will result in recommendations for higher power purchase rates.

The pricing provisions in gas export contracts for cogeneration projects in the United States vary considerably. In general, producers have attempted to obtain indexing of the first year price to the extent of at least $50 \%$ to the purchasing utility's alternative natural gas supplies. For example, in the Midland cogeneration joint venture, the gas prices are indexed as to $50 \%$ to the avoided cost of power of Consumer's Power Company, the large Michigan utility to which the project is selling power, (its avoided cost is based primarily on coal) and 50\% to the average cost to Consumer's Power of natural gas under its longterm system gas contracts with its U.S. pipeline suppliers. Several export contracts follow a similar pattern. Contracts for sales to projects in New England often have the gas price indexed to the fossil fuel component of the NEPOOL index, which is currently $60 \%$ oil, $25 \%$ coal and $15 \%$ gas, with gas predicted to increase to $35 \%$ by 1996 . In more recent contracts, parties have agreed to use a particular index but have modified it to fit their needs by, for example, increasing the relative importance of the natural gas component.

Buyers and sellers may also provide for the gas price to be indexed as described above, say $50 \%$ to the U.S. utility's avoided coat, and $50 \%$ to its alternative long-term U.S. gas supplies, and provide for the pricing provisions to be renegotiated at selected intervals over the contract term and, failing agreement, for the price to be arbitrated. The arbitrators are directed to take into account criteria such as:

(a) the price being paid by gas purchasers in other North American gas markets for Alberta supplies;

(b) the prices being paid for other gas supplies delivered under comparable terms to buyers in regions where the cogeneration facility is located; and

(c) the prices of other energy sources that might be utilized in the cogenerator's facility, taking into account the difference in conversion efficiencies.

An alternative arbitration provision, contained in a contract between a Canadian producer and a cogenerator in Massachusetts, is for either party to ask to renegotiate the commodity pricing provisions on $\mathbf{9 0}$ days notice, with arbitration to follow in the event of disagreement. If the seller requests arbitration, the arbitrator is directed to take into account, among other things, the competitiveness of the seller's gas supply with other firm long-term gas supplies delivered to the city gate of LDCs in Connecticut, Massachusetts, and Rhode Island. If the cogenerator requests the renegotiation, the arbitrator must consider the gas price required to ensure dispatchability of the cogenerator's plant for $\mathbf{3 2 0}$ days/year. 


\section{Transportation}

Typically the cogenerator agrees to pay transportation demand and commodity tolls on NOVA, TCPL and the relevant U.S. pipeline systems, even though the delivery point may be neither at the U.S. border or the Alberta border. Since there is a relative scarcity of pipeline capacity, both the producer and the cogenerator may wish to hold that capacity. Given the operation of the TransCanada queue and the lengthy waiting list to obtain new service, a cogenerator would need to be assured of pipeline capacity, either directly or by way of a buy/sell agreement through the local distributor. In most recent contracts, the cogenerator holds capacity on all U.S. pipelines, TransCanada, and sometimes on Nova. Due to the fact that TCPL applies less stringent conditions on LDCs than on cogenerators with respect to the demonstration of gas supplies needed to comply with its precedent agreement, the cogenerator may find it advantageous to enter into buy/sell arrangements with a distributor, rather than contract directly for capacity on TransCanada.

\section{Prepurchase Options}

A few cogencrators and producers, for a number of business reasons, one of which is to fix the commodity price of gas, have entered into prepurchase arrangements, under which the cogenerator prepays for a 15-20 year supply of gas with a defined delivery schedule and with maximum daily, annual and term volumes. The contract is essentially a deliverability contract, with reserves allocated to the contract (with substitution allowed), to satisfy the ERCB and the National Energy Board (NEB). The producer warrants delivery of the gas over the contract period and provides some credit enhancement, such as a letter of credit, the value of which may decline over time as gas is delivered. The buyer pays a lump sum up-front cash payment equivalent to an agreed present value of 15-20 year supply of gas, a monthly operating charge per BTU, escalated at an agreed annual fixed rate, or the Consumer Price Index, which could be periodically adjusted to the market. The producer may view the prepayment on a unit basis as a substantial premium over its unit exploration costs, in which case the prepayment may represent rather inexpensive financing. From the purchaser's point of view, the prepurchase, even for a part of the total gas required for the project, may make lenders more ready to fund the project as it removes the risk of a very large increase in the commodity price.

\section{Conditions Precedent and Termination}

Since the gas contracts are often signed before the project financing is arranged, and may be required by the lenders as a condition of closing the permanent financing, they are typically conditional upon completion of project financing, as well as both seller and buyer obtaining the required regulatory approvals and pipeline transportation contracts. Some contracts contain milestones to the effect that if the cogenerator's project is not operational by a given date, the producer can terminate. In addition, some export contracts contain "regulatory out" clauses that state, for example, that if any federal regulatory agency in either country takes action with respect to the export or import of gas which makes the contract "virtually uneconomic," either party can terminate; in such circumstances the contract might provide that the two parties share the pipeline demand charges both in Canada and the United States on a 50-50 basis. A few recent contracts 
have permitted either the producer to terminate the contract after five years, for the contract to terminate in the absence of agreement on a contract price reopener, or for the purchaser to cancel the contract after a few years on payment of a penalty.

\section{Regulatory}

Sellers supplying gas to cogeneration projects outside Canada require an NEB export licence. Under its market based procedure, as noted earlier, the NEB has approved a wide variety of commercial arrangements between gas sellers and buyers. It presumes any contract negotiated at arms length to be in the public interest as well as the private interest of the parties. It has approved gas exports for cogeneration projects in the U.S. where there are no minimum take provisions, where either the seller or the buyer may terminate the agreement after two to four years (although in one such case the certificate was conditional on the market and supply remaining the same), and where the initial gas price was increased by a fixed percentage annually with not price redetermination opportunity until the eleventh year of a 15 year contract. It reduced the applied for licence term from 20 to 15 years where available reserves and deliverability coverage did not extend for 20 years, where no compelling commercial reasons were advanced for the 20-year term, and the ERCB permit was for a term of 15 years. The NEB has accepted the notion that a seller's proposed exploration program could supplement dedicated reserves for the second half of a 15 year contract. At the same time, in response to complaints from domestic distributors, the NEB indicated that it would address the issues of the contractual chain and assurances of take in the near future.

\section{COGENERATION PROJECTS AS INVESTMENTS}

Some Canadian oil and gas producers should find investment in cogeneration facilities increasingly attractive. Given increasingly competitive gas markets, investment in gasfired cogeneration projects represents a way of securing a market, as well as generating a stable cash flow to offset the vagaries of exploration success in the producer's primary business. Finally, for cogeneration projects in Canada, the combination of the producer's ability to substantially leverage its investment due to the assured long-term revenue stream (cogeneration projects are typically $75 \%-80 \%$ debt financed) and the relatively attractive tax treatment, provide for very high returns. Cogeneration developers will sometimes find it attractive to have a producer as a partner in a project.

Class 34 of the Income Tax Act Regulations provides for accelerated capital cost allowances for eligible cogeneration assets of $25 \%, 50 \%$ and $25 \%$ in years one, two and three respectively. The eligible assets constitute virtually all of the equipment used in a typical gas-fired cogeneration facility. As noted earlier, the facility must generate a threshold amount of steam to qualify, but virtually any cogeneration project configuration will produce enough heat to qualify. What makes the provision particularly attractive for oil and gas producers is that, pursuant to some changes in the Regulations made in mid1990, the only companies that can take the accelerated depreciation, outside of the cogeneration developer or the steam host (if the latter were to develop and own the project) are so called "principal energy corporations" defined in the Regulations as companies engaged in the production, sale, distribution or transmission of energy. All 
other investors can take capital cost allowances only against income from the project itself. Moreover, the cogeneration developer, at least for the first few projects, is not likely to have sufficient taxable income from other projects against which to offset the capital cost on each new project. A cogeneration project generates a long-term stream of taxable income, but in the first 15 years or so, while project debt is retired, the taxable income will not be large relative to the available capital cost allowances.

Oil and gas distribution companies and transmission companies are typically regulated and may find it difficult to justify deducting the capital cost allowance from their utility income for tax purposes but not for rate making purposes. In a recent case in which ICG Utilities (Ontario) Ltd. proposed to do that, the Ontario Energy Board reserved the right to review, in subsequent rate cases, the income taxes purported to be included in the utility's cost of service. The utility had proposed a regulation prescribing for all time the regulatory accounting treatment of the deductions. It is likely that in Ontario, regulated utilities will participate in the cogeneration market through separate, affiliated companies, and the project capital cost allowance would therefore not be taken against utility income.

However, oil and gas producers in a current taxable position are able to take maximum advantage of this provision. Consider, as an example, an $80 \mathrm{MW}$ cogeneration facility to be constructed at a cost of $\$ 100$ million. Assume that three fully taxable oil and gas producers were to each own $25 \%$ of the project and that the cogeneration developer owned the remaining $25 \%$. Assume further that the project is $75 \%$ debt financed with the remaining equity contribution allocated equally among the four partners. A producer would make a $\$ 6.25$ million equity contribution to the project and borrow his $25 \%$ share of the $\$ 75$ million or about $\$ 19$ million. That producer's share of the available project capital cost allowance would be approximately $\$ 25$ million, allowing him tax savings (assuming for this hypothetical example a 50\% marginal tax rate) in years one, two, and three, of $\$ 3.25$ million, $\$ 6.5$ million and $\$ 3.25$ million respectively. Even allowing for the fact that the developer will wish to obtain a larger than pro rata share of project cash flow, the potential returns to the producer-investors, who would also likely be the gas suppliers, are very substantial.

There are different possibilities for structuring these investments. The limited partnership is a traditional investment vehicle which preserves limited liability while allowing for flow-through of tax benefits to the partners. The cogeneration developer would become the general partner of a limited partnership which would build the facility and the gas producers would become limited partners. In order to retain limited partner status, producers would not be able to participate in the management of the business. Care would have to be taken to ensure that being gas suppliers to the project would not disqualify them from limited partner status. The project debt would be incurred on a "project finance" basis, which is to say that the lender could look only to the revenues from the project itself to repay the loan, not to the other assets of either the general or the limited partners. The producers' liability in this case is limited to the capital that they have agreed to put into the partnership. On the other hand, the "at risk rules" of the Income Tax Act would limit the amount of a producer's tax savings to the amount it had at risk in the project, namely, its capital contribution. Since the debt is a project debt and not the producer's debt, the producer is not "at risk" for that amount. However, were the 
producer to borrow its full share of the project's cost and inject that amount into the partnership, it would be at risk for its full share (but its liability would be limited to that amount) and it could therefore take capital cost allowance on the full amount (\$25 million as in the example given earlier). The revenue from the project can be allocated among the developer and the producer-investors according to the terms of the limited partnership or joint venture agreement.

In order to claim the Class 34 accelerated capital cost allowance for cogeneration assets, the investors must first obtain a certificate from Energy, Mines and Resources Canada (EMR), qualifying the assets as eligible for Class 34 treatment. EMR will give a prior opinion based on the conceptual engineering data and approximate calculations of electricity and steam output. However, there have been instances where Revenue Canada have disagreed with EMR as to the eligibility of assets, based on their interpretation of recent tax cases, and it would be prudent to have discussions with Revenue Canada in the early stages of project planning, whether or not a formal ruling is applied for. 